University of Nebraska - Lincoln

DigitalCommons@University of Nebraska - Lincoln

USDA National Wildlife Research Center - Staff Publications
U.S. Department of Agriculture: Animal and Plant Health Inspection Service

2021

\title{
A framework for surveillance of emerging pathogens at the human-animal interface: Pigs and coronaviruses as a case study
}

Kim M. Pepin

USA National Wildlife Research Center, USDA-APHIS, kim.m.pepin@aphis.usda.gov

Ryan S. Miller

USDA APHIS, Ryan.S.Miller@aphis.usda.gov

Mark Q. Wilber

University of California, Santa Barbara, mqwilber@gmail.com

Follow this and additional works at: https://digitalcommons.unl.edu/icwdm_usdanwrc

Part of the Natural Resources and Conservation Commons, Natural Resources Management and Policy Commons, Other Environmental Sciences Commons, Other Veterinary Medicine Commons, Population Biology Commons, Terrestrial and Aquatic Ecology Commons, Veterinary Infectious Diseases Commons, Veterinary Microbiology and Immunobiology Commons, Veterinary Preventive Medicine, Epidemiology, and Public Health Commons, and the Zoology Commons

Pepin, Kim M.; Miller, Ryan S.; and Wilber, Mark Q., "A framework for surveillance of emerging pathogens at the human-animal interface: Pigs and coronaviruses as a case study" (2021). USDA National Wildlife Research Center - Staff Publications. 2426.

https://digitalcommons.unl.edu/icwdm_usdanwrc/2426

This Article is brought to you for free and open access by the U.S. Department of Agriculture: Animal and Plant Health Inspection Service at DigitalCommons@University of Nebraska - Lincoln. It has been accepted for inclusion in USDA National Wildlife Research Center - Staff Publications by an authorized administrator of DigitalCommons@University of Nebraska - Lincoln. 


\title{
A framework for surveillance of emerging pathogens at the human-animal interface: Pigs and coronaviruses as a case study
}

\author{
Kim M. Pepin ${ }^{\mathrm{a}, *}$, Ryan S. Miller ${ }^{\mathrm{b}}$, Mark Q. Wilber ${ }^{\mathrm{c}}$ \\ ${ }^{a}$ National Wildlife Research Center, Wildlife Services, Animal and Plant Health Inspection Service, United States Department of Agriculture, 4101 Laporte Ave., Fort \\ Collins, CO, 80526, United States \\ ${ }^{\mathrm{b}}$ Centers for Epidemiology and Animal Health, Veterinary Services, Animal and Plant Health Inspection Service, United States Department of Agriculture, 2150 Center \\ Ave., Fort Collins, CO, 80526, United States \\ ${ }^{\mathrm{c}}$ Ecology, Evolution, and Marine Biology, University of California, Santa Barbara, CA, 93106, United States
}

\section{A R T I C L E I N F O}

\section{Keywords:}

Coronavirus

Swine

Pig

Spillover

Surveillance

\begin{abstract}
A B S T R A C T
Pigs (Sus scrofa) may be important surveillance targets for risk assessment and risk-based control planning against emerging zoonoses. Pigs have high contact rates with humans and other animals, transmit similar pathogens as humans including CoVs, and serve as reservoirs and intermediate hosts for notable human pandemics. Wild and domestic pigs both interface with humans and each other but have unique ecologies that demand different surveillance strategies. Three fundamental questions shape any surveillance program: where, when, and how can surveillance be conducted to optimize the surveillance objective? Using theory of mechanisms of zoonotic spillover and data on risk factors, we propose a framework for determining where surveillance might begin initially to maximize a detection in each host species at their interface. We illustrate the utility of the framework using data from the United States. We then discuss variables to consider in refining when and how to conduct surveillance. Recent advances in accounting for opportunistic sampling designs and in translating serology samples into infection times provide promising directions for extracting spatio-temporal estimates of disease risk from typical surveillance data. Such robust estimates of population-level disease risk allow surveillance plans to be updated in space and time based on new information (adaptive surveillance) thus optimizing allocation of surveillance resources to maximize the quality of risk assessment insight.
\end{abstract}

\section{Introduction}

Pigs (Sus scrofa) share many pathogens with humans (Ruiz-Fons et al., 2008; Meng et al., 2009; Miller et al., 2017) and have been the source of notable human pandemics such as (H1N1)pdm09 virus (Smith et al., 2009). They also transmit a variety of coronaviruses (CoVs) (Miller et al., 2017; Cui et al., 2019; Wang et al., 2019; Leopardi et al., 2020), some of which show broad host-receptor usage (Li et al., 2018; Wang et al., 2019). While there is overwhelming evidence that bats have been important reservoirs for the evolution and spillover of zoonotic CoVs (Li et al., 2020b), the role of pigs is less well studied. In addition to high levels of contact with humans, several lines of evidence suggest pigs could be intermediate hosts, mixing vessels, or even reservoirs of new CoVs (Li et al., 2018; Wang et al., 2019; Leopardi et al., 2020), as has been suggested for influenza A viruses (Ma et al., 2008). In fact, it was recently suggested that the genome of SARS-CoV had a complicated history of recombination with alpha- and gamma-CoVs from multiple divergent taxa including bats, birds, mice, pigs, and humans (Su et al., 2016). The ongoing threat from persistence and transmission of influenza A genetic variants among wild birds, pigs, and humans (including frequent human-to-pig transmission (Nelson and Worobey, 2018), and repeated emergence of zoonotic CoVs in humans from different animal reservoirs, underscores the importance of better understanding the potential role of multiple animal hosts, including pigs, in the emergence and persistence of disease in humans. One step towards preparation for managing zoonotic disease emergence is to develop risk-based surveillance strategies that are rooted in the fundamental mechanisms of zoonotic emergence theory, ready for deployment as needed. Below we outline how to plan surveillance for an emerging zoonotic disease using CoVs as an example, assuming that pigs could be relevant reservoir, intermediate, or maintenance hosts to a novel CoV emergence event.

The zoonotic spillover framework of Lloyd-Smith et al. (2009)

\footnotetext{
* Corresponding author.

E-mail address: kim.m.pepin@usda.gov (K.M. Pepin).
} 
describes the sequential phases of zoonotic emergence: reservoir dynamics, spillover, stuttering chain transmission, followed by ongoing human-to-human transmission, where each phase is determined by ecological and evolutionary processes (Lloyd-Smith et al., 2009). The spillover phase of the framework was then expanded by Plowright et al. (2017) to describe the barriers of spillover as a series of bottlenecks that must align for zoonotic spillover to occur (Plowright et al., 2017). Key bottlenecks in the spillover process include: 1) Pathogen availability in the reservoir: e.g., host reservoir distribution and density, pathogen prevalence, infection intensity, survival outside the host and transmissibility (pathogen availability for spillover), 2) Interface connectivity: contact with humans (interhost-species connectivity), and 3) Success in the new host species: genetic pliability of the pathogen and low immunity in humans so that the pathogen can replicate well in humans (ability of the pathogen to be fit in a new host species). Similar bottlenecks would apply with humans as the 'reservoir' when considering transmission from humans to animals. Thus, for predicting risk in a system where both spillover and spillback could be important, the framework can be generalized as: pathogen availability in host 1 , interface connectivity, and pathogen availability in host 2 , assuming that host 1 and host 2 are receptive to each other's pathogens.

The CoV pathway to zoonotic spillover can involve multiple evolutionary processes, including mutation and recombination, and transmission among multiple host species (Zhao et al., 2004; Cotten et al., 2014; Su et al., 2016; Li et al., 2020b) before a cross-species transmission to humans results in successful human-to-human transmission. The role of spillover-spillback dynamics in the process of emergence is unknown. Similarly, our understanding of the order of evolutionary events, ecological conditions, and host species that allowed the last three $\mathrm{CoV}$ emergences (SARS-CoV, MERS, SARS-CoV-2) in humans remain poorly understood (Su et al., 2016; Li et al., 2020b). Below we describe the potential relevance of pigs in the emergence and persistence of new CoVs.

\section{Why might pigs contribute to emergence of zoonotic CoVs?}

\subsection{Pigs are abundant, widely distributed, and have frequent contact with} both humans and wildlife

As livestock, domestic pigs have high contact rates with humans, especially at county fairs (CDC, 2016) and on smaller, backyard or niche production farms that are widespread across human populations (Burdett et al., 2015). Similar to domestic pigs, wild pigs are widespread across the globe (Lewis et al., 2017). Wild pigs have been highly successful in both their native and non-native ranges and continue to expand geographically (Lewis et al., 2017; Snow et al., 2017; Aschim and Brook, 2019), suggesting that wild pig contact rates with humans and backyard domestic pigs are increasing rather than decreasing. Wild pigs contact a variety of wildlife species, including bats (Wang et al., 2018), while also contacting humans through hunting (Bevins et al., 2014), living in urban spaces (Stillfried et al., 2017), and intense control programs (Pepin et al., 2019b) or with backyard domestic pigs (Wyckoff et al., 2009; Wu et al., 2012). As such, pigs have been implicated in the emergence of novel influenza A viruses in humans (Brown, 2001; Hass et al., 2011), and human influenza A prevalence is positively correlated with influenza A prevalence in wild pigs (Pepin et al., 2019a). Thus, relative to other animal species, pigs may be quite connected to other reservoir species and humans concurrently, while supporting pathogen transmission and evolution with an ample supply of susceptible hosts.

\subsection{Several divergent CoVs are prevalent in pigs}

Pigs readily transmit a variety of CoVs (Cui et al., 2019; Wang et al., 2019). While only alpha- and beta-CoVs typically circulate in humans, alpha-, beta-, and delta-CoVs have been detected in pigs (Chan et al., 2013; Cui et al., 2019; Wang et al., 2019). Of the alpha-CoVs, the same genus as Middle Eastern respiratory syndrome CoV (MERS-CoV), the three most commonly studied and monitored alpha-CoVs in pigs are transmissible gastroenteritis virus (TGEV), porcine respiratory CoV (PRCV), and porcine epidemic diarrhea virus (PEDV). These viruses are highly prevalent and transmissible in domestic pigs (Li et al., 2018; Wang et al., 2019) and wild pigs (Kaden et al., 2009; Roic et al., 2012; Lee et al., 2016; Bevins et al., 2018), although surveys in wild pigs remain scarce. Additionally, a severe acute respiratory syndrome $\mathrm{CoV}$ (SARS-CoV)-like alpha-CoV named swine acute diarrhea syndrome-coronavirus (SADS-CoV) and porcine enteric alpha-CoV (PEAV) have recently emerged in pigs (causing widespread morbidity and mortality) likely through spillover from bats (Gong et al., 2017; Wang et al., 2018; Zhou et al., 2018). In addition to these alpha-CoVs, porcine delta-CoVs (PDCoV) are prevalent in domestic pigs (Li et al., 2018; Wang et al., 2019), but have not been surveyed in wild pigs to our knowledge. PDCoVs and SADS-CoV have been highlighted as high-risk for of a novel zoonotic spillover (Li et al., 2018; Edwards et al., 2020). In fact, there is evidence that PDCoV has spilled over into poultry (Boley et al., 2020). It has also been shown that several of these CoVs can remain infectious on animal feed for extended periods of time (up to 42 days for PDCoV and TGEV, and 7 days for PEDV; (Trudeau et al., 2017), suggesting that these CoVs could increase their chance of spillover with high environmental persistence. There is also one pig beta-CoV, the $\mathrm{CoV}$ genus that SARS-CoV and SARS CoV-2 belong to, that is highly prevalent in domestic swine and is named porcine hemagglutinating encephalomyelitis virus (PHEV) (Mora-Diaz et al., 2019; Wang et al., 2019), but it has not been detected in wild pigs (Moutelikova et al., 2016) (although surveillance has been minimal). In summary, CoVs from other host species are highly available for spillover into pigs, where the virus can successfully replicate.

\subsection{CoVs evolve rapidly and human CoVs can replicate in pigs}

Like many RNA viruses, CoVs evolve rapidly (compared with DNA viruses) through a combination of mutation, recombination, and purifying selection (Li et al., 2020b). Emergence of both SARS-CoV and SARS-CoV-2 were thought to be the product of recombination events in wildlife hosts, including pigs (Su et al., 2016; Cui et al., 2019; Li et al., 2020b). In fact, the SARS-CoV genome shows evidence of recombination with PEDV at some point in its evolutionary history (Su et al., 2016). Experiments have shown that SARS-CoV do not replicate well in juvenile pigs (Weingartl et al., 2004), while MERS-CoVs do (Vergara-Alert et al., 2017), although spillover of SARS-CoV from humans to domestic pigs was detected (Chen et al., 2005).

The science on SARS-CoV-2 is evolving rapidly and shows inconsistent findings on the potential role of pigs in SARS-CoV-2 epidemiology. While two experiments showed that juvenile pigs were not susceptible to SARS-CoV-2 inoculated at $<10^{6}$ PFU (Meekins et al., 2020; Shi et al., 2020), a more recent experiment showed that SARS-CoV-2 does replicate at low levels in 8 week old domestic pigs when inoculated oronasally at $10^{6} \mathrm{PFU}$ (Pickering et al., 2020) and that SARS-CoV-2 does infect and cause damage to cultured porcine cells (Meekins et al., 2020). Similarly, while multiple studies have demonstrated that pig ACE2 receptors (a mechanism of viral entry into host cells) show high affinity for SARS-CoV-2 spike protein binding (Wan et al., 2020; Zhai et al., 2020; Zhao et al., 2020), another suggests that pig ACE2 should have low compatibility for SARS-CoV-2 (Damas et al., 2020). However, the latter study also predicted that dog and mink ACE2 should have low to very low affinity for SARS-CoV-2, yet multiple cases and outbreaks in these species have been detected (Oreshkova et al., 2020; USDA-APHIS, 2020). Thus, our understanding of the infection mechanisms of SARS-CoV-2 and the potential role of pigs and other animals in the epidemiology of SARS-CoV-2 remains incomplete (Zhao et al., 2020).

Regardless of whether the currently circulating strains of SARS-CoVs are infectious to pigs, there is the possibility that human-infectious strains could mutate or recombine with prevalent porcine CoVs, 
expanding their host range further and expanding the reservoir of SARSCoVs. This kind of genetic pliability appears common based on the recent emergences of bat-like CoVs in pigs (Gong et al., 2017; Wang et al., 2018; Zhou et al., 2018), pig CoV genetic elements in SARS-CoV (Su et al., 2016), and frequent coinfection (Zhang, 2016) and recombination of CoVs in pigs and among pigs and other host species (Wang et al., 2019).

\section{Where should we do surveillance?}

With such potential for CoVs and other zoonotic pathogens to transmit between pigs and humans, it is useful to establish off-the-shelf guidelines for emerging disease surveillance, especially for wild pigs which frequently contact other wildlife species. Wildlife disease surveillance is challenging because animals are difficult to sample randomly across a geographic area or at a target proportion, and resources are typically limited (Park et al., 2013). Thus it is useful to guide surveillance programs spatially based on where risk might be highest targeted risk-based surveillance (Miller and Pepin, 2019). Using pigs and CoVs in the USA as a case study, we illustrate how risk factors can be used to develop guidance for triaging surveillance resources. In our example, the surveillance objective is risk assessment for either a new (pig to human) or reverse zoonosis (human to pig) that could lead to ongoing persistence or spatial spread. We assume that either would be of interest to control because spillover and ongoing transmission of a human $\mathrm{CoV}$ in pigs could have the risk of transmitting to other human populations or recombining with other pig CoVs and undergoing further evolutionary change. Applying the spillover framework of Plowright et al. (2017), we expect that risk of a CoV transmission among wild pigs and humans, for example, would be highest where virus availability in wild pigs and humans $\left(A_{w}\right.$ and $\left.A_{h}\right)$ is highest and where contact $\left(C_{w-h}\right)$ is highest (Fig. 1). Because alpha- and beta-CoVs are prevalent in both pigs and humans and pigs additionally have delta-CoVs that are thought to pose and emergence risk in humans (described above), we assume that an initial surveillance plan would involve all of these groups. Similarly, as bat-derived coronaviruses are known to emerge in pigs (Gong et al., 2017; Wang et al., 2018; Zhou et al., 2018) and bats are thought to have played a role in the generation of novel pandemic coronaviruses, it could be useful to surveil areas where bats and pigs have the most opportunity for contact. Other examples of risk factors to consider initially are described in Table 1.

Without considering hierarchical relationships of factors that determine $A$ and $C$, the simplest proxy for risk can be expressed as the

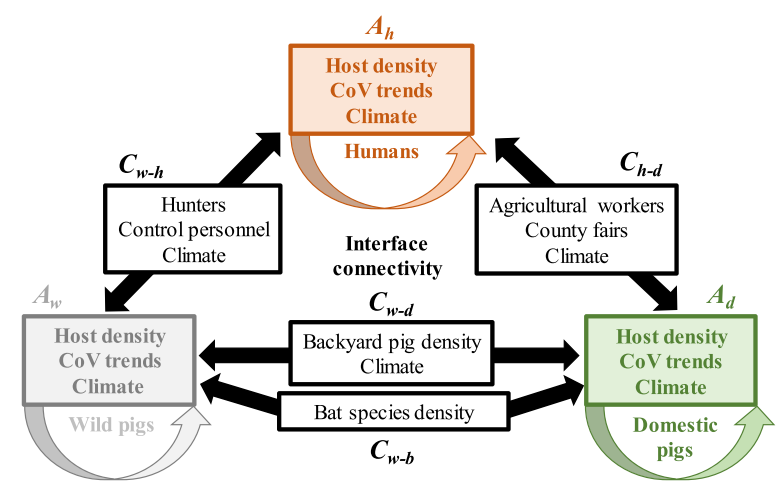

Fig. 1. Risk factors of the spillover-spillback process. Risk factors of pathogen availability within each host group are shown in the colored boxes - these factors affect the dynamics of pathogen availability within each host group. Risk factors that affect the contact and transmission between host groups (interface connectivity) are shown in white between the host groups that they connect. Factors that influence the entire system - both pathogen availability in hosts and interface connectivity - such as climate would be included only once in the relative risk framework. multiplicative process: $A_{w} \cdot A_{h} \cdot C_{w-h}$, with component risk factors (Table 1 ) also being multiplicative within $A$ and $C$. The relative risk of each spatial unit (here, counties) in the USA can then represented as,

$\prod_{r=1}^{R} \omega_{r} \theta_{j, r}$

where $\omega$ is the weight for risk factor $r$ and $\Theta_{j, r}$ is the relative risk score for risk factor $r$ in county $j$. Each risk factor, $\Theta_{r}$, is normalized from 0 to 1 using minimum-maximum normalization (i.e., with county values being relative to one another such that the highest score would be 1 and reflect the county with the highest risk factor score) to allow each risk factor to be considered equally. The weights, $\omega_{\mathrm{r}}$, then place importance on each risk factor relative to the other risk factors. This can either be defined by data or based on expert opinion. Here we weight each risk factor equally $\left(\omega_{r}=1\right.$; Fig. 2), however if there is evidence for the relative role of different risk factors other weighting schemes could be used. Ultimately, it would be useful to understand mechanistic or hierarchical relationships for the role of these risk factors in spillover so that their potential non-linear relationships could be accounted for in the risk assessment framework (e.g., (Plowright et al., 2017; Cross et al., 2019)).

\section{When should we do surveillance?}

\subsection{Temporal variation in risk}

The risk maps we present ignore temporal variation, yet temporal fluctuations in host demography, movement ecology, and pathogen prevalence determine transmission risk (Lloyd-Smith et al., 2009; Peel et al., 2014; Plowright et al., 2017; Scherer et al., 2019) and detection probability (Walton et al., 2016). Thus the risk maps we present for guiding surveillance design should be updated regularly with recent demographic and $\mathrm{CoV}$ prevalence data, or at least scaled over time to account for regular temporal fluctuations in transmission risk due to seasonal factors such as birth pulse dynamics (Peel et al., 2014) or mating behavior (Scherer et al., 2019). Meteorological factors, such as temperature and relative humidity, can also drive temporal changes in $\mathrm{CoV}$ transmission risk by affecting environmental persistence of CoVs (Kim et al., 2007; Casanova et al., 2010; Gardner et al., 2019; Altamimi and Ahmed, 2020; Gunthe et al., 2020). However, the relationship between meteorological factors and virus persistence is non-linear and dependent on multiple interacting meteorological variables (Casanova et al., 2010), which has made it complicated to determine how meteorology modifies transmission risk in host populations (Dowell and Ho, 2004; Tan et al., 2005; Cai et al., 2007). Unraveling how meteorological variables modify disease risk remains an important challenge for optimizing risk-based surveillance plans.

Also poorly understood is how reproductive phenology in wild pigs varies geographically (Macchi et al., 2010), in a way that could impact contact with domestic pigs (Wu et al., 2012). Reproductive phenology in both males and females is impacted by seasonal and inter-annual availability of forage, potentially affecting both birth rates within wild pigs and contact between wild and domestic pigs (Wu et al., 2012). Similarly, hunting rates (Johann et al., 2020) and wild pig control rates by trapping (Pepin et al., 2019b) (a technique that involves the more risk for transmission between humans and wild pigs) vary seasonally suggesting that seasonal variation in these activities could be used to optimize detection of spillover at the wild pig-human interface.

\section{How should we conduct surveillance?}

\subsection{Surveillance objectives}

Surveillance for pathogens in wild pigs is often designed to identify pathogen presence for objectives such as determining disease freedom, or to gain baseline information about emergence of new diseases or 
Table 1

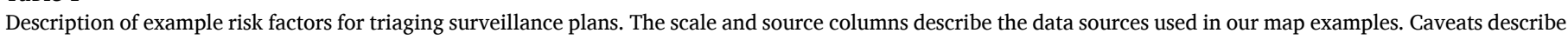

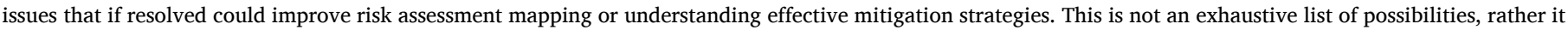

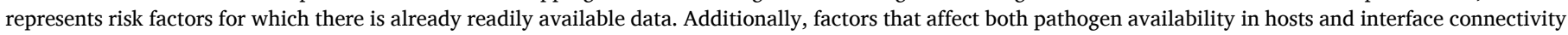
(e.g., climate) should be included only once in the relative risk framework.

\begin{tabular}{|c|c|c|c|c|c|}
\hline Risk factor & Type & Rationale & Scale & Source & Caveats \\
\hline \multicolumn{6}{|c|}{ Pathogen availability in hosts $(A)$} \\
\hline Host density & $\begin{array}{l}\text { A Pathogen } \\
\text { availability - all } \\
\text { host species }\end{array}$ & $\begin{array}{l}\text { Host density affects dynamics and prevalence } \\
\text { of CoVs in each host population }\end{array}$ & $\begin{array}{l}\text { County (All } \\
\text { data } \\
\text { streams) }\end{array}$ & $\begin{array}{l}\text { (Lewis et al., 2017) using } \\
\text { methods from (Lewis et al., } \\
\text { 2019) (USDA, 2020) ( } \\
\text { Institute, 2018) }\end{array}$ & $\begin{array}{l}\text { Wild pigs: density over time is important } \\
\text { because densities can fluctuate } \\
\text { dramatically due to birth pulses and } \\
\text { control efforts. } \\
\text { Commercial domestic pigs: Size of farms } \\
\text { may not correlate directly to risk due to } \\
\text { differences in farm connectivity and } \\
\text { biosecurity }\end{array}$ \\
\hline $\begin{array}{l}\text { CoV trends in } \\
\text { hosts }\end{array}$ & $\begin{array}{l}\text { A Pathogen } \\
\text { availability - all } \\
\text { host species }\end{array}$ & $\begin{array}{l}\text { Historical trends of CoV circulation in hosts } \\
\text { could represent hotspots for CoV availability in } \\
\text { hosts }\end{array}$ & $\begin{array}{l}\text { County (All } \\
\text { data } \\
\text { streams) }\end{array}$ & $\begin{array}{l}\text { (USDA-APHIS, 2015; Bevins } \\
\text { et al., 2018; Benatia et al., } \\
\text { 2020) }\end{array}$ & $\begin{array}{l}\text { Recent prevalence of specific 'high-risk' } \\
\text { CoVs would be a more direct risk metric } \\
\text { of pathogen availability }\end{array}$ \\
\hline Climate & $\begin{array}{l}\text { A Pathogen } \\
\text { availability - all } \\
\text { host species }\end{array}$ & $\begin{array}{l}\text { CoV transmission within host species will be } \\
\text { higher in colder climates because CoVs persist } \\
\text { longer outside hosts in colder climates } \\
\text { providing an additional source of infection } \\
\text { within host species (i.e., higher virus } \\
\text { availability). }\end{array}$ & County & $\begin{array}{l}\text { nCLIMGRID (Vose et al., } \\
\text { 2014) }\end{array}$ & $\begin{array}{l}\text { Relationship of climate and CoV } \\
\text { prevalence remains poorly understood, } \\
\text { is likely non-linear, and depends on } \\
\text { other factors that could modify its } \\
\text { effects. }\end{array}$ \\
\hline \multicolumn{6}{|c|}{ Interface connectivity $(C)$} \\
\hline Hunters & $\begin{array}{l}C_{w-h} \\
\text { Wild pig } \\
\downarrow \\
\text { Humans }\end{array}$ & $\begin{array}{l}\text { Areas with more hunting have more wild pig- } \\
\text { human contact }\end{array}$ & State & (USFWS, 2020) & $\begin{array}{l}\text { Some hunting practices may be more } \\
\text { conducive to human-wild pig contact } \\
\text { than others. }\end{array}$ \\
\hline $\begin{array}{l}\text { Control } \\
\text { personnel }\end{array}$ & $\begin{array}{l}C_{w-h} \\
\text { Wild pig } \\
\downarrow \\
\text { Humans }\end{array}$ & $\begin{array}{l}\text { Areas with higher rates of wild pig control have } \\
\text { higher contact among humans and wild pig }\end{array}$ & State & (Labor, 2019) & $\begin{array}{l}\text { Some control techniques and local } \\
\text { practices may be more conducive to } \\
\text { human-wild pig contact than others. }\end{array}$ \\
\hline Climate & $\begin{array}{l}\text { C } \\
\text { All hosts } \\
\downarrow \\
\text { All hosts }\end{array}$ & $\begin{array}{l}\text { CoV transmission among host species will be } \\
\text { higher in colder climates because CoVs persist } \\
\text { longer outside hosts in colder climates } \\
\text { providing enhanced environmental } \\
\text { transmission among host species (i.e., direct } \\
\text { contact with environmental surfaces). }\end{array}$ & County & $\begin{array}{l}\text { nCLIMGRID (Vose et al., } \\
\text { 2014) }\end{array}$ & $\begin{array}{l}\text { Relationship of climate and transmission } \\
\text { remains poorly understood, is likely non- } \\
\text { linear, and depends on other factors that } \\
\text { could modify its effects. }\end{array}$ \\
\hline $\begin{array}{l}\text { Agricultural } \\
\text { workers }\end{array}$ & $\begin{array}{l}C_{d-h} \\
\text { Domestic pigs } \\
\uparrow \\
\text { Humans }\end{array}$ & $\begin{array}{l}\text { Agricultural workers (including animal } \\
\text { caretakers and slaughterhouse workers) have } \\
\text { the highest contact rates with domestic pigs }\end{array}$ & State & (USDA, 2020) & $\begin{array}{l}\text { Some types of agricultural workers may } \\
\text { have more risky contacts than others }\end{array}$ \\
\hline County fairs & $\begin{array}{l}C_{d-h} \\
\text { Domestic pigs } \\
\downarrow \\
\text { Humans }\end{array}$ & $\begin{array}{l}\text { County fairs allow increased interaction among } \\
\text { humans and domestic pigs }\end{array}$ & County & (Fairgrounds, 2020) & $\begin{array}{l}\text { The relationship of county fairs to } \\
\text { contact might not be related to } A_{d} \text { and } A_{\mathrm{h}} \\
\text { in the same county because humans may } \\
\text { travel from other counties to attend fairs }\end{array}$ \\
\hline $\begin{array}{l}\text { Bat species } \\
\text { density }\end{array}$ & $\begin{array}{l}C_{w-b} \\
\text { Wild pigs } \\
\uparrow \\
\text { Bats (affects } A_{w} \text { ) }\end{array}$ & $\begin{array}{l}\text { Higher bat species densities present a higher } \\
\text { spillover risk for CoVs into pigs that could act as } \\
\text { intermediate hosts for further evolution or } \\
\text { transmission to humans }\end{array}$ & County & (States, 2011) & $\begin{array}{l}\text { Best to use the bat species that are most } \\
\text { suspected for the spillover of risky CoVs } \\
\text { (see (Olival et al., 2020) for recent } \\
\text { analysis of North American bat species) }\end{array}$ \\
\hline $\begin{array}{l}\text { Backyard pig } \\
\text { density }\end{array}$ & $\begin{array}{l}C_{w-d} \\
\text { Domestic pigs } \\
\uparrow \\
\text { Wild pigs }\end{array}$ & $\begin{array}{l}\text { Backyard operations often have low biosecurity } \\
\text { allowing direct and indirect contact with wild } \\
\text { pigs thus areas with higher backyard pig } \\
\text { densities would have higher risk of } \\
\text { transmission among wild and domestic pigs }\end{array}$ & County & (USDA, 2020) & $\begin{array}{l}\text { Some landscapes and local practices may } \\
\text { be more conducive to backyard-wild pig } \\
\text { contact than others }\end{array}$ \\
\hline
\end{tabular}

where diseases of agricultural concern may occur (Pedersen et al., 2012, 2013; Pedersen et al., 2015; Bevins et al., 2018). Surveillance programs with these objectives provide useful foundational information for developing risk-based surveillance plans. However, for the surveillance objective here of informing risk assessment and response to cross-species disease emergence, we need to target locations that are most likely to lead to cross-species transmission and ongoing spread of disease in the spillover host population (i.e., areas where pathogen availability and interface connectivity are high). Pathogen availability can be determined by population-level quantities that describe the current status of disease risk such as prevalence (per capita number of cases at a given time), incidence (per capita number of cases over time), force of infection (rate at which susceptible hosts become infected), or $\mathrm{R}_{\mathrm{e}}$ (effective reproduction number; the average number of individuals that an infected individual transmits to). Incidence, force of infection, and $R_{e}$ are more functional epidemiological metrics of pathogen availability

because they describe 'transmission risk' - how likely the disease is to transmit to other hosts (and therefore persist), whereas prevalence only describes how many hosts are currently impacted (current pathogen availability) rather than the likelihood of ongoing transmission. Functional epidemiological metrics are especially useful for optimizing surveillance and control programs (Ferguson et al., 2001; Lessler and Cummings, 2016; Routledge et al., 2018) because they can be used to quantify factors that drive transmission risk thus providing more refined predictions about where pathogen availability for spillover will be highest. Thus, surveillance aimed at quantifying functional epidemiological metrics can provide better prediction about where to focus more expensive and intensive sampling for genetic markers of emergence risk.

\subsection{Opportunistic sampling designs and assay error}

Estimating functional epidemiological metrics is challenging using 


\section{a) Relative Risk Rank}
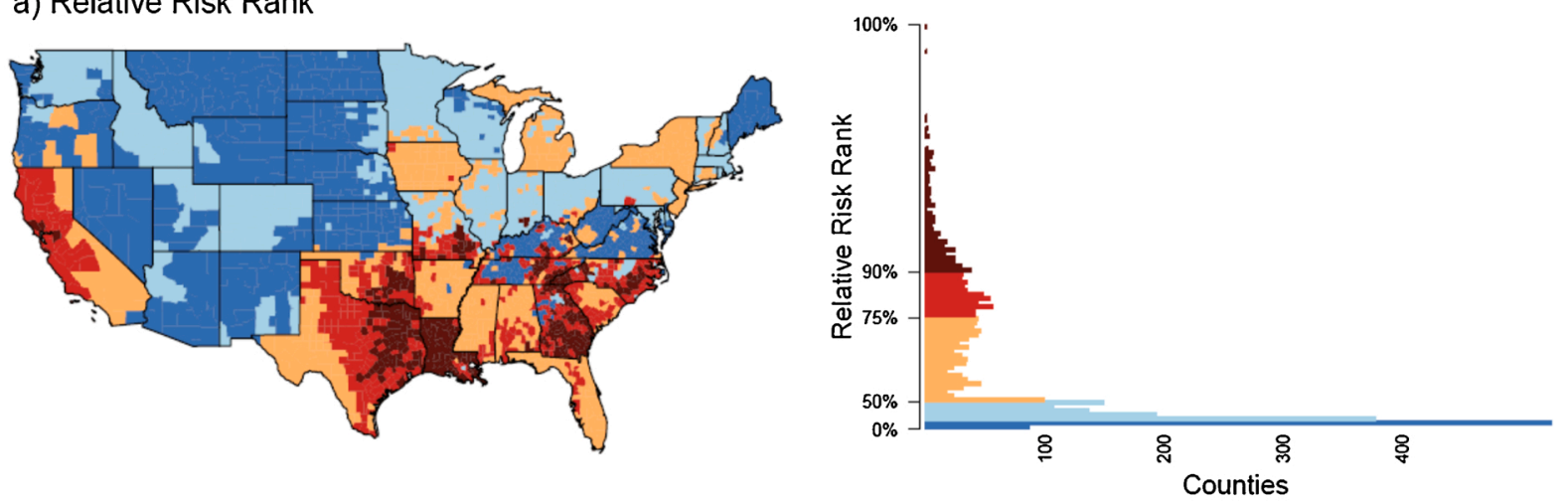

b) Wild pigs $\left(A_{w}\right)$

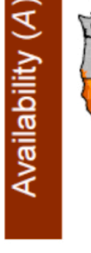

ত্ত

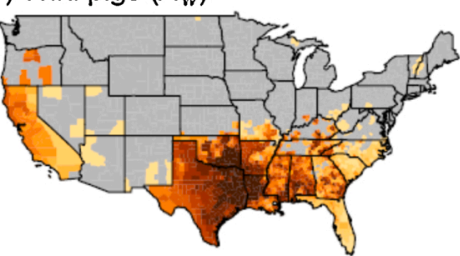

e) Wild pigs $<->$ Domestic pigs $\left(C_{w-b}\right)$

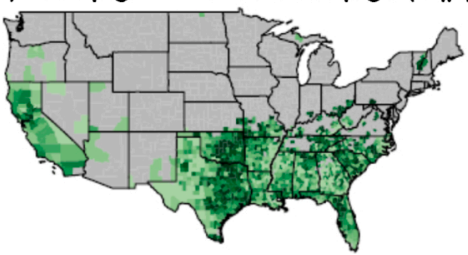

c) Domestic pigs $\left(A_{d}\right)$

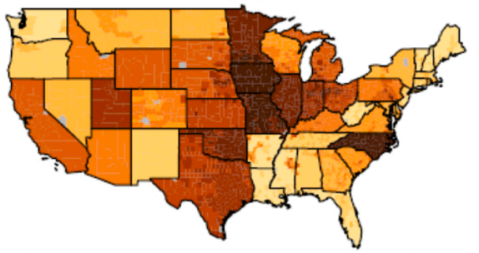

f) Domestic pigs $<->$ Humans $\left(C_{h-d}\right)$

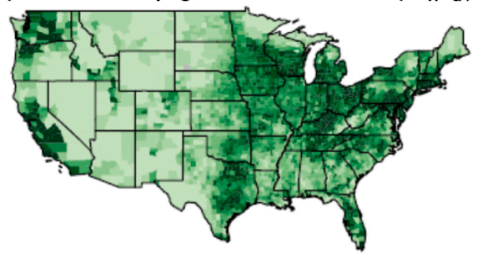

d) Humans $\left(A_{h}\right)$

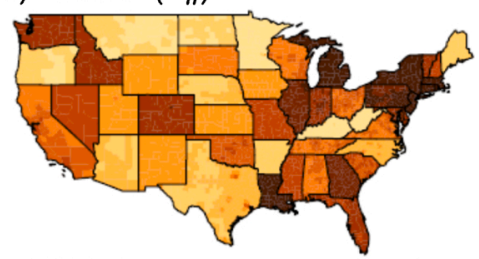

g) Wild pigs $<\rightarrow>$ Humans $\left(C_{w-h}\right)$

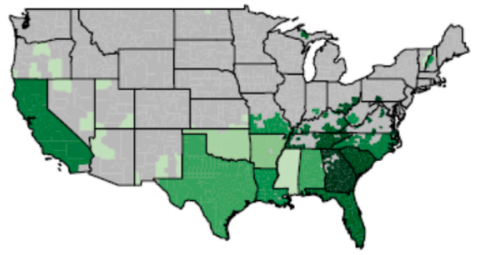

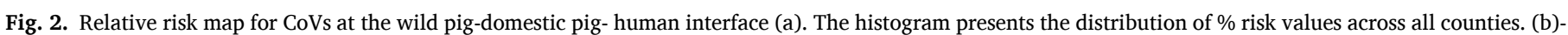

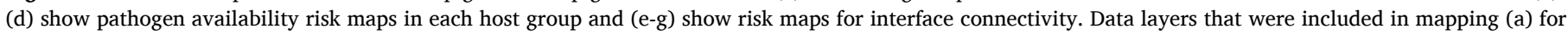

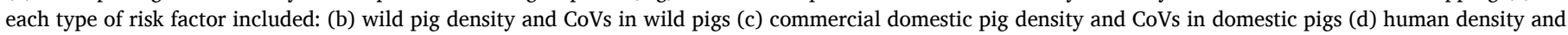

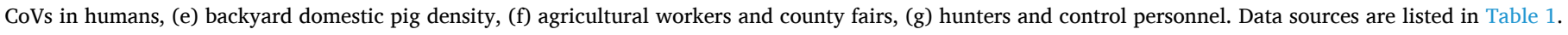

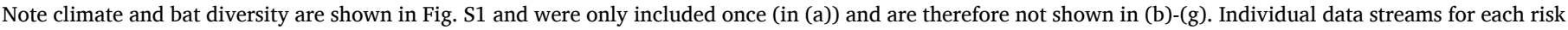
layer of pathogen availability and connectivity are shown in Figs. S2 and S3.

typical surveillance data because many surveillance systems are opportunistic (e.g., (Pedersen et al., 2012; Lee et al., 2016; Smietanka et al., 2016; Bevins et al., 2018; Bertelloni et al., 2020)) to maximize the number of samples that can be collected on a very limited budget. Thus, there is uneven sampling in space and time and maps of apparent prevalence (number of positive samples over total samples across space) mainly reflect the sampling design rather than providing information about how disease risk varies spatially (Wilber et al., 2020). Applying survival analysis to surveillance data can help remove bias induced by temporally uneven sampling efforts. Survival analysis is widely applicable to commonly-collected disease surveillance data (Pepin et al., 2019a; Wilber et al., 2020), suggesting that functional epidemiological metrics can be gleaned from opportunistic sampling designs when the sampling design biases are accounted for. A second approach is to apply state-space models that infer epidemiological metrics while accounting for reporting biases (Chen et al., 2012; Miller, 2017; Pepin et al., 2017a; Baker et al., 2019; Tabak et al., 2019). These approaches can be especially useful for informing surveillance design by estimating the amount of under-reporting (Chen et al., 2012), which types of surveillance methods are most informative (Davis et al., 2019), or where additional surveillance might best inform epidemiological metrics of interest and management (Davis et al., 2019). A separate problem from opportunistic sampling designs is assay error. That is, sometimes the test of a sample will falsely conclude no evidence of the target pathogen (sensitivity) or will falsely conclude evidence of a pathogen (specificity). These sources of error can be substantial (Gilbert et al., 2013), and can be accounted for in epidemiological estimates of disease risk (Tabak et al., 2019).

\subsection{Surveillance for antibodies}

In wildlife hosts, it is common for surveillance systems to search for antibodies (Elbers et al., 2003; Pedersen et al., 2015; Bevins et al., 2018; Elfadil et al., 2018) instead of pathogens because pathogens are more difficult to find - especially those that have short infectious periods. Serosurveillance data are often reported as zero/one data - a host has either been exposed or not to a pathogen. The threshold for determining whether a host is seropositive is based on a predetermined cutoff of the ratio between antibody quantity (signal) and procedural noise (i.e. the signal to noise ratio, (Gilbert et al., 2013)). However, recent developments in quantitative antibody analyses have shown that the signal to noise ratio itself can be used to estimate when hosts were infected with a pathogen (Borremans et al., 2016; Pepin et al., 2017b) and have highlighted opportunities to use serological data to estimate functional epidemiological metrics through time (Borremans et al., 2016; Pepin et al., 2017b; Gamble et al., 2020; Hay et al., 2020). Moreover, integrating multiple streams of data, such as data on viral load, virus presence/absence, and host age, with quantitative antibody data can further improve inference on estimates (Borremans et al., 2016; Wilber et al., 2020). While longitudinal laboratory data on within-host infection dynamics facilitate inference of functional epidemiological metrics from serosurveillance data (Pepin et al., 2017b), they are not strict prerequisites (Wilber et al., 2020). For example, Gamble et al. (2020) showed that longitudinal data from the field in the form of mark-recapture data can be integrated with serosurveillance data to provide estimates of functional epidemiological metrics. Thus, for acute pathogens such as CoVs that may be difficult to find in wildlife hosts, 
serosurveillance data can be used to quantify functional epidemiological metrics which, compared to seroprevalence data, can improve seasonal predictions of when spillover risk might be greatest, helping further optimize the allocation of surveillance resources.

\subsection{Adaptive surveillance}

Adaptive management is a valuable concept for optimizing spatial allocation of limited resources. In adaptive management frameworks, management is structured to improve learning about the system by iterating between monitoring that reduces uncertainty about key drivers of management outcomes and updating management strategies based on the improved knowledge (Williams et al., 2009). Similarly a surveillance plan for emerging CoVs in pigs could be implemented adaptively in order to optimize the amount learned based on the surveillance objectives, current conditions, and most recent insight, e.g., (Clow et al., 2019; Miller and Pepin, 2019). To implement adaptive surveillance there needs to be methods and personnel in place for regular assessments of risk from the surveillance data, in a manner that is appropriate for the surveillance objective and sampling design. As surveillance data are collected according to the initial surveillance plan, analyses to estimate the relative role of specific risk factors in predicting cases will then allow weighting schemes of the risk factors in the plan to be updated to refine the surveillance plan (increase accuracy and precision) and maximize the amount learned from the data based on available funding. For example, if initial surveillance failed to identify any ongoing chains of transmission for CoVs in wild pigs despite suspected pathogen introduction (suggesting that $\mathrm{R}_{0}<1$ ), increased weight and thus increased surveillance effort could be allocated to regions with a high human-animal interface where stuttering chains of transmission could be more easily detected. Designing adaptive surveillance plans is especially important for pre-emerging diseases because management objectives are likely to change from predominantly risk assessment to predominantly control if the disease emerges in an area (Clow et al., 2019). In addition to an adaptive design, the plan might also need flexibility in diagnostic assays. For example, during pre-emergence surveillance pan-CoV diagnostics (Zhang, 2016; Li et al., 2020a) can be conducted that are then followed up with diagnostic assays for specific strains in areas where CoVs are detected most frequently, which may allow more informative surveillance in the same budget (Zhang, 2016).

We described a starting point for an adaptive surveillance plan for disease emergence at the wildlife-livestock-human interface based on current knowledge and available data for risk factors. As knowledge of spatial transmission risk improves using the baseline plan, the surveillance design can be adapted based on a mechanistic description for how the risk factors predict spillover among host groups (Cross et al., 2019), which could be used to optimize control strategies. Given our a priori ignorance on seasonality and age-specific prevalence of CoVs in wild pigs, we recommend that initial surveillance sampling be evenly distributed across age groups and time. Analyses of initial surveillance data can then reveal whether the timing of surveillance should be adapted based on demographic fluctuations or seasonal changes in host movement. An initial surveillance plan could also benefit from including $\mathrm{CoV}$ serosurveillance, which would improve detection of previous transmission and thus evidence of viral presence. To maximize information gained from all the available analytic tools, serosurveillance programs should consider collecting and reporting both quantitative antibody data and viral presence/absence data, and host demographic data as well as considering small-scale laboratory or field studies that can generate longitudinal infection data. Together these data will provide the best opportunity to implement adaptive serosurveillance to uncover potential seasonal mechanisms underlying pig infection risk to CoVs, which will also help to optimize sampling designs for more expensive genetic assays that can reveal transmission among host groups or identify high-risk strains or genes.

\section{Conclusions and recommendations}

Pigs transmit a variety of CoVs, some of which have come from bats and humans. They frequently contact humans and potentially bats, and co-infections and recombination of CoVs occur in pigs. Together these observations suggest that pigs are a useful surveillance target for guarding against emergence and ongoing transmission of new CoVs. They also suggest that agricultural workers, hunters, and personnel working on control of wild pigs should wear appropriate personal protective equipment when contacting pigs directly or contacting control equipment or environmental features that pigs may have contaminated. Currently, movement of wild pigs by humans occurs frequently in the USA (Tabak et al., 2017; Hernandez et al., 2018), suggesting not only the opportunity for intimate contact with humans and wild pigs but also a mechanism for broader spatial dissemination. This type of capture and release should be avoided to minimize the spatial spread and evolution of new CoV strains. Our work outlines a plan for risk-based surveillance of disease emergence at the wildlife-livestock-human interface that can be implemented adaptively to optimize detection, learning about transmission risk factors, and prediction of transmission hotspots.

\section{Acknowledgements}

KMP was funded by the National Feral Swine Damage Management Program of the United States Department of Agriculture, Animal and Plant Health Inspection Service. Reference herein to any specific commercial product, process, or service by trade name, trademark, manufacturer, or otherwise does not constitute or imply its endorsement, recommendation, or favoring by the United States Government or any agency thereof. The views and opinions of the authors expressed herein do not necessarily state or reflect those of the United States Government or any agency thereof.

\section{Appendix A. Supplementary data}

Supplementary material related to this article can be found, in the online version, at doi:https://doi.org/10.1016/j.prevetmed.2021.10 5281.

\section{References}

Altamimi, A., Ahmed, A.E., 2020. Climate factors and incidence of Middle East respiratory syndrome coronavirus. J. Infect. Public Health 13, 704-708.

Aschim, R.A., Brook, R.K., 2019. Evaluating cost-effective methods for rapid and repeatable national scale detection and mapping of invasive species spread. Sci RepUk 9.

Baker, L., Matthiopoulos, J., Muller, T., Freuling, C., Hampson, K., 2019. Optimizing spatial and seasonal deployment of vaccination campaigns to eliminate wildlife rabies. Philosophical Transactions of the Royal Society B-Biological Sciences 374.

Benatia, D., Godefroy, R., Lewis, J., 2020. Estimating COVID-19 prevalence in the United States: a sample selection model approach. MedRixv. https://doi.org/10.1101/ 2020.1104.1120.20072942.

Bertelloni, F., Mazzei, M., Cilia, G., Forzan, M., Felicioli, A., Sagona, S., Bandecchi, P., Turchi, B., Cerri, D., Fratini, F., 2020. Serological survey on bacterial and viral pathogens in wild boars hunted in Tuscany. Ecohealth 17, 85-93.

Bevins, S.N., Pedersen, K., Lutman, M.W., Gidlewski, T., Deliberto, T.J., 2014. Consequences associated with the recent range expansion of nonnative feral swine. Bioscience 64, 291-299.

Bevins, S.N., Lutman, M., Pedersen, K., Barrett, N., Gidlewski, T., Deliberto, T.J., Franklin, A.B., 2018. Spillover of swine coronaviruses, United States. Emerg Infect Dis 24, 1390-1392.

Boley, P.A., Alhamo, M.A., Lossie, G., Yadav, K.K., Vasquez-Lee, M., Saif, L.J., Kenney, S. P., 2020. Porcine deltacoronavirus infection and transmission in poultry, United States. Emerg Infect Dis 26, 255-264.

Borremans, B., Hens, N., Beutels, P., Leirs, H., Reijniers, J., 2016. Estimating time of infection using prior serological and individual information can greatly improve incidence estimation of human and wildlife infections. PLoS Comput. Biol. 12.

Brown, I.H., 2001. The pig as an intermediate host for influenza a viruses between birds and humans. In: Osterhaus, A.D.M., Cox, N., Hampson, A.W. (Eds.), Options for the Control of Influenza Iv, pp. 173-178.

Burdett, C.L., Kraus, B.R., Garza, S.J., Miller, R.S., Bjork, K.E., 2015. Simulating the distribution of individual livestock farms and their populations in the United States: 
an example using domestic swine (Sus scrofa domesticus) farms. PLoS One 10, e0140338.

Cai, Q.C., Lu, J., Xu, Q.F., Guo, Q., Xu, D.Z., Sun, Q.W., Yang, H., Zhao, G.M., Jiang, Q. W., 2007. Influence of meteorological factors and air pollution on the outbreak of severe acute respiratory syndrome. Public Health 121, 258-265.

Casanova, L.M., Jeon, S., Rutala, W.A., Weber, D.J., Sobsey, M.D., 2010. Effects of air temperature and relative humidity on coronavirus survival on surfaces. Appl. Environ. Microbiol. 76, 2712-2717.

CDC, 2016. Key Facts for People Exhibiting Pigs at Fairs. https://www.cdc.gov/flu/pd f/swineflu/fair_exhibitor_factsheet.pdf.

Chan, J.F.W., To, K.K.W., Tse, H., Jin, D.Y., Yuen, K.Y., 2013. Interspecies transmission and emergence of novel viruses: lessons from bats and birds. Trends Microbiol. 21, 544-555.

Chen, W.J., Yan, M.H., Yang, L., Ding, B.L., He, B., Wang, Y.Z., Liu, X.L., Liu, C.H., Zhu, H., You, B., Huang, S.Y., Zhang, J.G., Mu, F., Xiang, Z., Feng, X.L., Wen, J., Fang, J.Q., Yu, J., Yang, H.M., Wang, J., 2005. SARS-associated coronavirus transmitted from human to pig. Emerg Infect Dis 11, 446-448.

Chen, S., Fricks, J., Ferrari, M.J., 2012. Tracking measles infection through non-linear state space models. J R Stat Soc C-Appl 61, 117-134.

Clow, K.M., Leighton, P.A., Pearl, D.L., Jardine, C.M., 2019. A framework for adaptive surveillance of emerging tick-borne zoonoses. One Health-Amsterdam 7.

Cotten, M., Watson, S.J., Zumla, A.I., Makhdoom, H.Q., Palser, A.L., Ong, S.H., Al Rabeeah, A.A., Alhakeem, R.F., Assiri, A., Al-Tawfiq, J.A., Albarrak, A., Barry, M., Shibl, A., Alrabiah, F.A., Hajjar, S., Balkhy, H.H., Flemban, H., Rambaut, A., Kellam, P., Memish, Z.A., 2014. Spread, circulation, and evolution of the middle east respiratory syndrome coronavirus. Mbio 5.

Cross, P.C., Prosser, D.J., Ramey, A.M., Hanks, E.M., Pepin, K.M., 2019. Confronting models with data: the challenges of estimating disease spillover. Philosophical Transactions of the Royal Society B-Biological Sciences 374 .

Cui, J., Li, F., Shi, Z.L., 2019. Origin and evolution of pathogenic coronaviruses. Nat. Rev. Microbiol. 17, 181-192.

Damas, J., Hughes, G.M., Keough, K.C., Painter, C.A., Persky, N.S., Corbo, M., Hiller, M., Koepfli, K.P., Pfenning, A.R., Zhao, H., Genereux, D.P., Swofford, R., Pollard, K.S., Ryder, O.A., Nweeia, M.T., Lindblad-Toh, K., Teeling, E.C., Karlsson, E.K., Lewin, H. A., 2020. Broad host range of SARS-CoV-2 predicted by comparative and structural analysis of ACE2 in vertebrates. Proc Natl Acad Sci U S A 117, 22311-22322.

Davis, A.J., Kirby, J.D., Chipman, R.B., Nelson, K.M., Xifara, T., Webb, C.T., Wallace, R., Gilbert, A.T., Pepin, K.M., 2019. Not all surveillance data are created equal—a multimethod dynamic occupancy approach to determine rabies elimination from wildlife. J. Appl. Ecol. 56, 2551-2561.

Dowell, S.F., Ho, M.S., 2004. Seasonality of infectious diseases and severe acute respiratory syndrome - what we don't know can hurt us. Lancet Infect. Dis. 4, 704-708.

Edwards, C.E., Yount, B.L., Graham, R.L., Leist, S.R., Hou, Y.J., Dinnon 3rd, K.H., Sims, A.C., Swanstrom, J., Gully, K., Scobey, T.D., Cooley, M.R., Currie, C.G., Randell, S.H., Baric, R.S., 2020. Swine acute diarrhea syndrome coronavirus replication in primary human cells reveals potential susceptibility to infection. Proc Natl Acad Sci U S A 117, 26915-26925.

Elbers, A.R.W., Dekker, A., Dekkers, L.J.M., 2003. Serosurveillance of wild deer and wild boar after the epidemic of foot-and-mouth disease in the Netherlands in 2001. Vet. Rec. 153, 678-681.

Elfadil, A.A.M., Ahmed, A.G., Abdalla, M.O., Gumaa, E., Osman, O.H., Younis, A.E., AbuObeida, A., Al-Hafufi, A.N., Saif, L.J., Zaki, A., Ai-Rumaihi, A., Al-Harbi, N., Kasem, S., Al-Brahim, R.H., Ai-Sahhaf, A., Bayoumi, F.E., Al-Dowairij, A., Qasim, I A., 2018. Epidemiological study of Middle East respiratory syndrome coronavirus infection in dromedary camels in Saudi Arabia, April-May 2015. Rev. Sci. Tech. Off. Int. Epizoot. 37, 985-997.

Fairgrounds, C.Ca., 2020. Homeland Infrastructure Foundation-Level Data (HIFLD). https://hifld-geoplatform.opendata.arcgis.com/datasets/convention-centers-fa irgrounds.

Ferguson, N.M., Donnelly, C.A., Anderson, R.M., 2001. Transmission intensity and impact of control policies on the foot and mouth epidemic in Great Britain. Nature 413, 542-548.

Gamble, A., Garnier, R., Chambert, T., Gimenez, O., Boulinier, T., 2020. Next-generation serology: integrating cross-sectional and capture-recapture approaches to infer disease dynamics. Ecology 101.

Gardner, E.G., Kelton, D., Poljak, Z., Van Kerkhove, M., von Dobschuetz, S., Greer, A.L. 2019. A case-crossover analysis of the impact of weather on primary cases of Middle East respiratory syndrome. BMC Infect. Dis. 19.

Gilbert, A.T., Fooks, A.R., Hayman, D.T.S., Horton, D.L., Muller, T., Plowright, R., Peel, A.J., Bowen, R., Wood, J.L.N., Mills, J., Cunningham, A.A., Rupprecht, C.E., 2013. Deciphering serology to understand the ecology of infectious diseases in wildlife. Ecohealth 10, 298-313.

Gong, L., Li, J., Zhou, Q.F., Xu, Z.C., Chen, L., Zhang, Y., Xue, C.Y., Wen, Z.F., Cao, Y.C., 2017. A new Bat-HKU2-like coronavirus in swine, China, 2017. Emerg Infect Dis 23 1607-1609.

Gunthe, S.S., Swain, B., Patra, S.S., Amte, A., 2020. On the global trends and spread of the COVID-19 outbreak: preliminary assessment of the potential relation between location-specific temperature and UV index. Journal of Public Health-Heidelberg.

Hass, J., Matuszewski, S., Cieslik, D., Haase, M., 2011. The role of swine as "mixing vessel" for interspecies transmission of the influenza A subtype H1N1: a simultaneous Bayesian inference of phylogeny and ancestral hosts. Infect. Genet. Evol. 11, 437-441.

Hay, J.A., Minter, A., Ainslie, K., Lessler, J., Yang, B., Cummings, D.A.T., Kuchaski, A.J., Riley, S., 2020. An open source tool to infer epidemiological and immunologicla dynamics from serological data: sersolver. PLoS Comput. Biol. 16, e1007840.
Hernandez, F.A., Parker, B.M., Pylant, C.L., Smyser, T.J., Piaggio, A.J., Lance, S.L., Milleson, M.P., Austin, J.D., Wisely, S.M., 2018. Invasion ecology of wild pigs (Sus scrofa) in Florida, USA: the role of humans in the expansion and colonization of an invasive wild ungulate. Biol. Invasions 20, 1865-1880.

Institute, N.C., 2018. US Population Data-1969-2018. Surveillance, Epidemiology, and End Results Program. https://www.seer.cancer.gov/popdata.

Johann, F., Handschuh, M., Linderoth, P., Dormann, C.F., Arnold, J., 2020. Adaptation of wild boar (Sus scrofa) activity in a human-dominated landscape. BMC Ecol. 20.

Kaden, V., Lange, E., Hanel, A., Hlinak, A., Mewes, L., Hergarten, G., Irsch, B., Dedek, J., Bruer, W., 2009. Retrospective serological survey on selected viral pathogens in wild boar populations in Germany. Eur. J. Wildl. Res. 55, 153-159.

Kim, S.W., Ramakrishnan, M.A., Raynor, P.C., Goyal, S.M., 2007. Effects of humidity and other factors on the generation and sampling of a coronavirus aerosol. Aerobiologia 23, 239-248.

Labor, U.Do., 2019. Occupational Employment Statistics May 2019. Bureau of Labor Statistics. www.bls.gov/oes/.

Lee, D.U., Kwon, T., Je, S.H., Yoo, S.J., Seo, S.W., Sunwoo, S.Y., Lyoo, Y.S., 2016. Wild boars harboring porcine epidemic diarrhea virus (PEDV) may play an important role as a PEDV reservoir. Vet. Microbiol. 192, 90-94.

Leopardi, S., Terregino, C., De Benedictis, P., 2020. Silent circulation of coronaviruses in pigs. Vet. Rec. 186, 323-323.

Lessler, J., Cummings, D.A.T., 2016. Mechanistic models of infectious disease and their impact on public health. Am. J. Epidemiol. 183, 415-422.

Lewis, J.S., Farnsworth, M.L., Burdett, C.L., Theobald, D.M., Gray, M., Miller, R.S., 2017. Biotic and abiotic factors predicting the global distribution and population density of an invasive large mammal. Sci Rep-Uk 7.

Lewis, J.S., Corn, J.L., Mayer, J.J., Jordan, T.R., Farnsworth, M.L., Burdett, C.L., VerCauteren, K.C., Sweeney, S.J., Miller, R.S., 2019. Historical, current, and potential population size estimates of invasive wild pigs (Sus scrofa) in the United States. Biol. Invasions 21, 2373-2384.

Li, W.T., Hulswit, R.J.G., Kenney, S.P., Widjaja, I., Jung, K., Alhamo, M.A., van Dieren, B., van Kuppeveld, F.J.M., Saif, L.J., Bosch, B.J., 2018. Broad receptor engagement of an emerging global coronavirus may potentiate its diverse crossspecies transmissibility. P Natl Acad Sci USA 115, E5135-E5143.

Li, B., Si, H.R., Zhu, Y., Yang, X.L., Anderson, D.E., Shi, Z.L., Wang, L.F., Zhou, P., 2020a. Discovery of bat coronaviruses through surveillance and probe capture-based nextgeneration sequencing. Msphere 5.

Li, X., Giorgi, E.E., Marichann, M.H., Foley, B., Xiao, C., Kong, X., Chen, Y., Korber, B., Gao, F., 2020b. Emergence of SARS-CoV-2 through recombination and strong purifying selection. BioRixv. https://doi.org/10.1101/2020.03.20.000885.

Lloyd-Smith, J.O., George, D., Pepin, K.M., Pitzer, V.E., Pulliam, J.R.C., Dobson, A.P., Hudson, P.J., Grenfell, B.T., 2009. Epidemic dynamics at the human-animal interface. Science 326, 1362-1367.

Ma, W., Kahn, R.E., Richt, J.A., 2008. The pig as a mixing vessel for influenza viruses: human and veterinary implications. J. Mol. Genet. Med. 3, 158-166.

Macchi, E., Cucuzza, A.S., Badino, P., Odore, R., Re, F., Bevilacqua, L., Malfatti, A., 2010. Seasonality of reproduction in wild boar (Sus scrofa) assessed by fecal and plasmatic steroids. Theriogenology 73, 1230-1237.

Meekins, D.A., Morozov, I., Trujillo, J.D., Gaudreault, N.N., Bold, D., Carossino, M., Artiaga, B.L., Indran, S.V., Kwon, T., Balaraman, V., Madden, D.W., Feldmann, H., Henningson, J., Ma, W., Balasuriya, U.B.R., Richt, J.A., 2020. Susceptibility of swine cells and domestic pigs to SARS-CoV-2. Emerg. Microbes Infect. 9, 2278-2288.

Meng, X.J., Lindsay, D.S., Sriranganathan, N., 2009. Wild boars as sources for infectious diseases in livestock and humans. Philosophical Transactions of the Royal Society BBiological Sciences 364, 2697-2707.

Miller, R.S., 2017. Interaction among Societal and Biological Drivers of Policy At the Wildlife-agricultural Interface. Biology. Colorado State University, p. 201.

Miller, R.S., Pepin, K.M., 2019. BOARD INVITED REVIEW: prospects for improving management of animal disease introductions using disease-dynamic models. J. Anim. Sci. 97, 2291-2307.

Miller, R.S., Sweeney, S.J., Slootmaker, C., Grear, D.A., Di Salvo, P.A., Kiser, D., Shwiff, S.A., 2017. Cross-species transmission potential between wild pigs, livestock, poultry, wildlife, and humans: implications for disease risk management in North America. Sci Rep-Uk 7.

Mora-Diaz, J.C., Pineyro, P.E., Houston, E., Zimmerman, J., Gimenez-Lirola, L.G., 2019. Porcine hemagglutinating encephalomyelitis virus: a review. Front. Vet. Sci. 6, 12.

Moutelikova, R., Dufkova, L., Kamler, J., Drimaj, J., Plhal, R., Prodelalova, J., 2016. Epidemiological survey of enteric viruses in wild boars in the Czech Republic: first evidence of close relationship between wild boar and human rotavirus A strains. Vet. Microbiol. 193, 28-35.

Nelson, M.I., Worobey, M., 2018. Origins of the 1918 pandemic: revisiting the swine "Mixing vessel" hypothesis. Am. J. Epidemiol. 187, 2498-2502.

Olival, K.J., Cryan, P.M., Amman, B.R., Baric, R.S., Blehert, D.S., Brook, C.E., Calisher, C. H., Castle, K.T., Coleman, J.T.H., Daszak, P., Epstein, J.H., Field, H., Frick, W.F., Gilbert, A.T., Hayman, D.T.S., Ip, H.S., Karesh, W.B., Johnson, C.K., Kading, R.C., Kingston, T., Lorch, J.M., Mendenhall, I.H., Peel, A.J., Phelps, K.L., Plowright, R.K., Reeder, D.M., Reichard, J.D., Sleeman, J.M., Streicker, D.G., Towner, J.S., Wang, L. F., 2020. Possibility for reverse zoonotic transmission of SARS-CoV-2 to free-ranging wildlife: a case study of bats. PLoS Pathog. 16, e1008758.

Oreshkova, N., Molenaar, R.J., Vreman, S., Harders, F., Oude Munnink, B.B., Hakze-van der Honing, R.W., Gerhards, N., Tolsma, P., Bouwstra, R., Sikkema, R.S., Tacken, M. G., de Rooij, M.M., Weesendorp, E., Engelsma, M.Y., Bruschke, C.J., Smit, L.A., Koopmans, M., van der Poel, W.H., Stegeman, A., 2020. SARS-CoV-2 infection in farmed minks, the Netherlands, April and May 2020. Euro Surveill. 25. 
Park, A.W., Magori, K., White, B.A., Stallknecht, D.E., 2013. When more transmission equals less disease: reconciling the disconnect between disease hotspots and parasite transmission. PLoS One 8.

Pedersen, K., Bevins, S.N., Schmit, B.S., Lutman, M.W., Milleson, M.P., Turnage, C.T., Bigelow, T.T., DeLiberto, T.J., 2012. Apparent prevalence of swine brucellosis in feral swine in the United States. Human-Wildlife Interactions 6, 38-47.

Pedersen, K.I., Bevins, S.N., Baroch, J.A., Cumbee, J.C., Chandler, S.C., Woodruff, B.S., Bigelow, T.T., DeLiberto, T.J., 2013. Pseudorabies in feral swine in the United States, 2009-2012. J. Wildl. Dis. 49, 709-713.

Pedersen, K., Pabilonia, K.L., Anderson, T.D., Bevins, S.N., Hicks, C.R., Kloft, J.M., Deliberto, T.J., 2015. Widespread detection of antibodies to Leptospira in feral swine in the United States. Epidemiol. Infect. 143, 2131-2136.

Peel, A.J., Pulliam, J.R.C., Luis, A.D., Plowright, R.K., O'Shea, T.J., Hayman, D.T.S., Wood, J.L.N., Webb, C.T., Restif, O., 2014. The effect of seasonal birth pulses on pathogen persistence in wild mammal populations. P Roy Soc B-Biol Sci 281.

Pepin, K.M., Davis, A.J., Streicker, D.G., Fischer, J.W., VerCauteren, K.C., Gilbert, A.T., 2017a. Predicting spatial spread of rabies in skunk populations using surveillance data reported by the public. Plos Neglect Trop D 11.

Pepin, K.M., Kay, S.L., Golas, B.D., Shriner, S.S., Gilbert, A.T., Miller, R.S., Graham, A.L., Riley, S., Cross, P.C., Samuel, M.D., Hooten, M.B., Hoeting, J.A., Lloyd-Smith, J.O., Webb, C.T., Buhnerkempe, M.G., 2017b. Inferring infection hazard in wildlife populations by linking data across individual and population scales. Ecol. Lett. 20, 275-292.

Pepin, K.M., Pedersen, K., Wan, X.F., Cunningham, F.L., Webb, C.T., Wilber, M.Q., 2019a. Individual-level antibody dynamics reveal potential drivers of influenza a seasonality in wild pig populations. Integr. Comp. Biol. 59, 1231-1242.

Pepin, K.M., Wolfson, D.W., Miller, R.S., Tabak, M.A., Snow, N.P., VerCauteren, K.C., Davis, A.J., 2019b. Accounting for heterogeneous invasion rates reveals management impacts on the spatial expansion of an invasive species. Ecosphere 10.

Pickering, B.S., Smith, G., Pinette, M.M., Embury-Hyatt, C., Moffat, E., Marszal, P., Lewis, C.E., 2020. Susceptibility of domestic swine to experimental infection with SARS-CoV-2. BioRixiv. https://doi.org/10.1101/2020.09.10.288548.

Plowright, R.K., Parrish, C.R., McCallum, H., Hudson, P.J., Ko, A.I., Graham, A.L., LloydSmith, J.O., 2017. Pathways to zoonotic spillover. Nat. Rev. Microbiol. 15, 502-510.

Roic, B., Jemersic, L., Terzic, S., Keros, T., Balatinec, J., Florijancic, T., 2012. Prevalence of antibodies to selected viral pathogens in wild boars (sus scrofa) in croatia in 2005 . 06 and 2009-10. J. Wildl. Dis. 48, 131-137.

Routledge, I., Cheyez, J.E.R., Cucunuba, Z.M., Rodriguez, M.G., Guinovart, C., Gustafson, K.B., Schneider, K., Walker, P.G., Ghani, A.C., Bhatt, S., 2018. Estimating spatiotemporally varying malaria reproduction numbers in a near elimination setting. Nat. Commun. 9.

Ruiz-Fons, F., Segales, J., Gortazar, C., 2008. A review of viral diseases of the European wild boar: effects of population dynamics and reservoir role. Vet. J. 176, 158-169.

Scherer, C., Radchuk, V., Staubach, C., Muller, S., Blaum, N., Thulke, H.H., KramerSchadt, S., 2019. Seasonal host life-history processes fuel disease dynamics at different spatial scales. J. Anim. Ecol. 88, 1812-1824.

Shi, J., Wen, Z.F., Zhong, G., Yang, H.M., Wang, C., Huang, B., Liu, R., He, X., Shuai, L., Sun, Z., Zhao, Y., Liu, P., Liang, L., Cui, P., Wang, J., Zhang, X., Guan, Y., Tan, W., Wu, G., Chen, H., Bu, Z., 2020. Susceptibility of ferrets, cats, dogs, and other domesticated animals to SARS-coronavirus 2. Science. https://doi.org/10.1126/ science.abb7015.

Smietanka, K., Wozniakowski, G., Kozak, E., Niemczuk, K., Fraczyk, M., Bocian, L., Kowalczyk, A., Pejsak, Z., 2016. African swine fever epidemic, Poland, 2014-2015. Emerg Infect Dis 22, 1201-1207.

Smith, G.J.D., Vijaykrishna, D., Bahl, J., Lycett, S.J., Worobey, M., Pybus, O.G., Ma, S.K., Cheung, C.L., Raghwani, J., Bhatt, S., Peiris, J.S.M., Guan, Y., Rambaut, A., 2009. Origins and evolutionary genomics of the 2009 swine-origin H1N1 influenza A epidemic. Nature 459, 1122-U1107.

Snow, N.P., Jarzyna, M.A., VerCauteren, K.C., 2017. Interpreting and predicting the spread of invasive wild pigs. J. Appl. Ecol. 54, 2022-2032.

States, N.Aot.U., 2011. North American Bat Ranges, 1830-2008. http://purl.stanford. edu/pz329xp4277.

Stillfried, M., Fickel, J., Borner, K., Wittstatt, U., Heddergott, M., Ortmann, S., KramerSchadt, S., Frantz, A.C., 2017. Do cities represent sources, sinks or isolated islands for urban wild boar population structure? J. Appl. Ecol. 54, 272-281.

Su, S., Wong, G., Shi, W.F., Liu, J., Lai, A.C.K., Zhou, J.Y., Liu, W.J., Bi, Y.H., Gao, G.F., 2016. Epidemiology, genetic recombination, and pathogenesis of coronaviruses. Trends Microbiol. 24, 490-502.

Tabak, M.A., Piaggio, A.J., Miller, R.S., Sweitzer, R.A., Ernest, H.B., 2017. Anthropogenic factors predict movement of an invasive species. Ecosphere 8.

Tabak, M.A., Pedersen, K., Miller, R.S., 2019. Detection error influences both temporal seroprevalence predictions and risk factors associations in wildlife disease models. Ecol. Evol. 9, 10404-10414.
Tan, J.G., Mu, L.N., Huang, J.X., Yu, S.Z., Chen, B.H., Yin, J., 2005. An initial investigation of the association between the SARS outbreak and weather: with the view of the environmental temperature and its variation. J. Epidemiol. Community Health 59, 186-192.

Trudeau, M.P., Verma, H., Sampedro, F., Urriola, P.E., Shurson, G.C., Goyal, S.M., 2017. Environmental persistence of porcine coronaviruses in feed and feed ingredients. PLoS One 12.

USDA, 2020. Quick Stats. http://quickstats.nass.usda.gov/.

USDA-APHIS, 2015. In: Services, V. (Ed.), Swine Enteric Coronavirus Introduction to the United States: Root Cause Investigation Report.

USDA-APHIS, 2020. Confirmed Cases of SARS-CoV-2 in Animals in the United States. https://www.aphis.usda.gov/aphis/ourfocus/animalhealth/sa_one_health/sars -cov-2-animals-us.

USFWS, 2020. Historical Hunting License Data. https://www.fws.gov/wsfrprograms/sub pages/licenseinfo/hunting.htm.

Vergara-Alert, J., van den Brand, J.M.A., Widagdo, W., Munoz, M., Raj, V.S., Schipper, D., Solanes, D., Cordon, I., Bensaid, A., Haagmans, B.L., Segales, J., 2017. Livestock susceptibility to infection with middle east respiratory syndrome coronavirus. Emerg Infect Dis 23, 232-240.

Vose, R., Applequist, S., Squires, M., Durre, I., Menne, M.J., Williams Jr, C.N., Fenimore, C., Gleason, K., Arndt, D., 2014. Gridded 5km GHCN-daily temperature and precipitation dataset (nCLIMGRID) version 1. In: Information, N.N.C.f.E (Ed.), Maximum Temperature, Minimum Temperature, Average Temperature, and Precipitation. https://doi.org/10.7289/V5SX6B56.

Walton, L., Marion, G., Davidson, R.S., White, P.C.L., Smith, L.A., Gavier-Widen, D. Yon, L., Hannant, D., Hutchings, M.R., 2016. The ecology of wildlife disease surveillance: demographic and prevalence fluctuations undermine surveillance. J. Appl. Ecol. 53, 1460-1469.

Wan, Y., Shang, J., Graham, R., Baric, R.S., Li, F., 2020. Receptor recognition by the novel coronavirus from Wuhan: an analysis based on decade-long structural studies of SARS coronavirus. J. Virol. 94.

Wang, L., Su, S., Bi, Y.H., Wong, G., Gao, G.F., 2018. Bat-origin coronaviruses expand their host range to pigs. Trends Microbiol. 26, 466-470.

Wang, Q., Vlasova, A.N., Kenney, S.P., Saif, L.J., 2019. Emerging and re-emerging coronaviruses in pigs. Curr. Opin. Virol. 34, 39-49.

Weingartl, H.M., Copps, J., Drebot, M.A., Marszal, P., Smith, G., Gren, J., Andonova, M., Pasick, J., Kitching, P., Czub, M., 2004. Susceptibility of pigs and chickens to SARS coronavirus. Emerg Infect Dis 10, 179-184.

Wilber, M.Q., Webb, C.T., Cunningham, F.L., Pedersen, K., Wan, X.F., Pepin, K.M., 2020. Inferring seasonal infection risk at population and regional scales from serology samples. Ecology 101.

Williams, B.K., Szaro, R.C., Shapiro, C.D., 2009. In: Department of the Interior, A.M.W.G (Ed.), The U.S. Department of the Interior Technical Guide, pp. 1-72. DOI, Washington, DC.

Wu, N., Abril, C., Thomann, A., Grosclaude, E., Doherr, M.G., Boujon, P., RyserDegiorgis, M.P., 2012. Risk factors for contacts between wild boar and outdoor pigs in Switzerland and investigations on potential Brucella suis spill-over. BMC Vet. Res. 8.

Wyckoff, A.C., Henke, S.E., Campbell, T.A., Hewitt, D.G., VerCauteren, K.C., 2009. Feral swine contact with domestic swine: a serologic survey and assessment of potential for disease transmission. J. Wildl. Dis. 45, 422-429.

Zhai, X., Sun, J., Yan, Z., Zhang, J., Zhao, J., Zhao, Z., Gao, Q., He, W.T., Veit, M., Su, S., 2020. Comparison of severe acute respiratory syndrome coronavirus 2 spike protein binding to ACE2 receptors from human, pets, farm animals, and putative intermediate hosts. J. Virol. 94.

Zhang, J.Q., 2016. Porcine deltacoronavirus: overview of infection dynamics, diagnostic methods, prevalence and genetic evolution. Virus Res. 226, 71-84.

Zhao, Z.M., Li, H.P., Wu, X.Z., Zhong, Y.X., Zhang, K.Q., Zhang, Y.P., Boerwinkle, E., Fu, Y.X., 2004. Moderate mutation rate in the SARS coronavirus genome and its implications. BMC Evol. Biol. 4.

Zhao, J., Cui, W., Tian, B., 2020. The potential intermediate hosts for SARS-CoV-2. Front. Microbiol. 11, 580137.

Zhou, P., Fan, H., Lan, T., Yang, X.L., Shi, W.F., Zhang, W., Zhu, Y., Zhang, Y.W., Xie, Q. M., Mani, S., Zheng, X.S., Li, B., Li, J.M., Guo, H., Pei, G.Q., An, X.P., Chen, J.W., Zhou, L., Mai, K.J., Wu, Z.X., Li, D., Anderson, D.E., Zhang, L.B., Li, S.Y., Mi, Z.Q., He, T.T., Cong, F., Guo, P.J., Huang, R., Luo, Y., Liu, X.L., Chen, J., Huang, Y., Sun, Q., Zhang, X.L., Wang, Y.Y., Xing, S.Z., Chen, Y.S., Sun, Y., Li, J., Daszak, P., Wang, L.F., Shi, Z.L., Tong, Y.G., Ma, J.Y., 2018. Fatal swine acute diarrhoea syndrome caused by an HKU2-related coronavirus of bat origin. Nature 556, 255-258. 